DOI (Article): https://doi.org/10.31108/2.2021.2.23.7

УДК 159.9

\title{
Оксана Креденцер
}

\section{ПРОФЕСІЙНА САМОЕФЕКТИВНІСТЬ ПЕРСОНАЛУ ОСВІТНІХ ОРГАНІЗАЦІЙ: ТЕОРЕТИЧНИЙ АНАЛІЗ ТА ЕМПІРИЧНЕ ДОСЛІДЖЕННЯ}

\begin{abstract}
Креденцер Оксана. Професійна самоефективність персоналу освітніх організацій: теоретичний аналіз та емпіричне дослідження.

Bступ. Професійна самоефективність персоналу освітніх організацій виступає одним із важливих чинників підвищення ефективності його діяльності та забезпечення психологічного здоров'я. організацій.

Мета: здійснити теоретичний та емпіричний аналіз професійної самоефективності персоналу освітніх

Методи. Для проведення дослідження використовувались теоретичні (аналіз, систематизація, узагальнення), емпіричні методи («Шкала професійної самоефективності (коротка версія)», анкетапаспортичка) та статистичні (описові статистики, кореляційний аналіз, дисперсійний аналіз (ANOVA)).

Результати. Визначено професійну самоефективність як систему суб'єктивних уявлень про здатність успішно діяти в ситуаціях, пов'язаних з педагогічною діяльністю, та з іншими професійними контекстами, яка має очінюючий характер $і$ забезпечує регуляцію дій, спрямованих на досягнення професійних ичілей, за рахунок формування суджень про свою здатність успішно вирішити поставлені робочі завдання.

Констатовано, шо у освітян спостерігається недостатній рівень розвитку їх переконаності у здатності успішно виконувати завдання, пов'язані з їх роботою. Професійна самоефективність пов'язана з такими характеристиками персоналу як посада та стаж на посаді. А також пов'язана з віком організації.
\end{abstract}

Висновки. Отримані дані свідчать про необхідність розробки спечіальних психологічних технологій щодо розвитку професійної самоефективності з урахуванням встановлених закономірностей.

Ключові слова: самоефективність, професійна самоефективність, персонал, організація, персонал освітніх організацій, задоволеність роботою, психологічне здоров'я.

Kredetser, Oksana. Educational organization staff's occupational self-efficacy: theoretical analysis and empirical research.

Introduction. Occupational self-efficacy of staff of educational organizations is an important factor in staff's work performance and mental health.

Aim: to carry out theoretical and empirical analyses of professional self-efficacy of staff of educational organizations.

Methods. Theoretical (analysis, systematization, generalization), empirical (Occupational Self-Efficacy Scale (short version), questionnaire-passport) and statistical methods (descriptive statistics, correlation analysis, analysis of variance (ANOVA)).

Results. Educators' occupational self-efficacy is defined as a system of their subjective ideas about their ability to act successfully in situations related to teaching activities and other professional contexts, which have an evaluative nature and regulate educators' actions aimed at achieving work goals through the judgments about educators' ability to cope with work tasks.

It was stated that educators had a weak (low-level) belief in their abilities to successfully perform work tasks. Occupational self-efficacy is related to staff's position and length of service as well as to the organization's age.

Conclusions. The obtained data show the need for special psychological technologies to develop educators' occupational self-efficacy based on the research findings.

Key words: self-efficacy, occupational self-efficacy, staff, organization, staff of educational organizations, job satisfaction, mental health

Креденцер Оксана. Профессиональная самоэффективность персонала образовательных организаций: теоретический анализ и эмпирическое исследование.

Вступление. Профессиональная самоэффективность персонала образовательньх организаций выступает одним из важных факторов повышения эффективности его деятельности и обеспечения психологического здоровья.

Цель: осуществить теоретический и эмпирический анализ профессиональной самоэффективности персонала образовательных организаций.

Методы. Для проведения исследования использовались теоретические (анализ, систематизация, обобщение), эмпирические методь («Шкала профессиональной самоэффективности (краткая версия)», анкета- 
паспортичка) и статистические (описательные статистики, корреляционный анализ, дисперсионный анализ (ANOVA)).

Результаты. Определена профессиональная самоэффективность как система субъективных представлений о способности успешно действовать в ситуациях, связанных с педагогической деятельностью, и с другими профессиональными контекстами, которая имеет оценивающий характер и обеспечивает регуляиию действий, направленных на достижение профессиональных иелей, за счет формирования суждений о своей способности успешно решить поставленнье рабочие задачи.

Констатировано, что у педагогов наблюдается недостаточный уровень развития их уверенности в способности успешно решать задачи, связанные с их работой. Профессиональная самоэффективность связана с такими характеристиками персонала как должность и стаж в должности. А также связана с возрастом организации.

Выводы. Полученные данные свидетельствуют о необходимости разработки специальных психологических технологий по развитию профессиональной самоэффективности с учетом установленньх закономерностей.

Ключевые слова: самоэффективность, профессиональная самоэффективность, персонал, организация, персонал образовательных организаций, удовлетворенность работой, психологическое здоровье.

Вступ. Концепція самоефективності вперше була запропонована А. Бандурою ще в кінці 1970-х років і активно досліджувалася ним протягом двадцяти років. А. Бандура (1977) вважає, що привабливість результату і віра в позитивний результат недостатні для запуску мотивації суб'єкта. Необхідна також віра в свою здатність впоратися з даним видом діяльності. Самоефективність полягає в тому, наскільки компетентною почувається людина, виконуючи ту чи іншу справу. А. Бандура вважає, що самоефективність - центральна і найважливіша детермінанта людської поведінки. Згідно з даними, отриманими А. Бандурою і його колегами, люди з високою самоефективністю більш наполегливі, краще вчаться, а також володіють великою самоповагою, менш тривожні і менш схильні до депресій.

Ми визначаємо самоефективність як систему суб'єктивних уявлень про здатність успішно діяти в конкретних ситуаціях, яка має оцінюючий характер і забезпечує регуляцію дій, спрямованих на досягнення певних цілей, за рахунок формування суджень про свою здатність успішно вирішити поставлені завдання (О. Креденцер, 2016).

Хоча проблема самоефективності бере свій початок у клінічній психології, вона знайшла досить широке відображення в психологічних дослідженнях різних напрямів. Значний дослідницький інтерес самоефективність має і в рамках організащййної психологї̈.

Аналіз багатьох досліджень показує, що одним із вагомих предикторів ефективної професійної діяльності особистості є їі самоефективність (Abele \& Spurk, 2009; Judge \& Bono, 2001; Schyns \& Sczesny, 2010). Так, аналіз літератури та наші попередні дослідження показують, що самоефективність позитивно пов'язана з ефективністю діяльності персоналу організацій (Judge \& Bono, 2001; Stajkovic \& Luthans, 1998), задоволеністю роботою (Judge \& Bono, 2001; Креденцер, 2019) та відданістю організації (Rigotti, Schyns, \& Mohr, 2008).

Аналіз літератури також показує, що проблема самоефективності досліджувалась в організаціях різних соціально-економічних сфер, зокрема в освітніх організаціях (Kim \& Buric', 2020; Friedman \& Farber, 1992; Slovak, 2010 та ін.).

Зазначимо, що проблема самоефективності персоналу освітніх організацій досліджувалась і вітчизняними вченими. Так, аналізувались особливості організаційної культури освітніх організацій залежно від самоефективності керівників (Бондарчук, 2018), підприємницька самоефективність персоналу освітніх організацій як чинник розвитку їх підприємницької активності та задоволеності працею (Креденцер, 2019), самоефективність та задоволеність професійною діяльністю викладачів університетів (Кузнєцова, Нікішина, 2018) та ін.

Водночас аналіз літератури та наш досвід роботи показав, що в організаційному контексті зміст та наповненість самоефективності необхідно конкретизувати в залежності від виду професійної діяльності та особливостей діяльності певної організації. Одним із таких видів самоефективності, на думку B. Schyns, S. Sczesny (2010), є «професійна самоефективність».

Аналіз робіт вітчизняних психологів показав, що професійну самоефективність досліджували в контексті, по-перше, професійної підготовки студентів (Музика, 2018, 2020). Розглядаючи самоефективність як чинник професіоналізації студентів, О. Музика зазначає, що формуванню професійної самоефективності студентів можуть сприяти такі умови, за яких вони матимуть можливість набути ціннісного досвіду розвитку й оцінки професійних компетентностей у взаємодії з усіма суб'єктами освітнього процесу. Важливою умовою успішної професіоналізації, на думку авторки, $\epsilon$ 
включення компонентів самоефективності, зокрема професійних здібностей, у ціннісно-мотиваційні схеми професійного й особистісного саморозвитку студентів.

А. Линенко (2019) аналізує проблему професійної самоефективності як педагогічної проблеми в контексті підготовки майбутніх вчителів. Авторка зазначає, що підготовка висококваліфікованих, конкурентоздатних педагогічних кадрів у закладах вищої освіти пов'язана 3 формуванням у них професійної самоефективності, яка сприяє досягненню успіху та «акме» у педагогічної діяльності, упевненості у вирішенні педагогічних завдань різної складності, самоповаги до себе як до професіонала, що веде до професійної зрілості і набуття вищих професійних абсолютів.

О. Кревська (2018), досліджуючи мотиваційні чинники професійної самоефективності в межах політичної реалізації особистості, визначає професійну самоефективність як усвідомленої здатності фахівця вирішувати складні професійні ситуації, ефективно виконувати професійну діяльність завдяки сформованим компетенціям i мобілізації здібностей. Зазначено, що метою професійної самоефективності особистості є як реалізація ï власних здібностей і компетентностей, так і відповідне моделювання зовнішньої поведінки, яка відповідає умовам професійних вимог. Виокремлено дві складові професійної самоефективності: особистісна складова - самоефективність особистості підкреслює як ії̈ почуття самоповаги і власної гідності, так і реальну компетентність (здатність, уміння вирішувати життєві проблеми); та результативна складова - як інтегральна здатність особистості бути ефективною за показниками професійних умов діяльності. Комплекс внутрішніх стандартів мотивації професійної самоефективності визначає міру особистісної успішності особистості й, відповідно, комплекс зовнішніх стандартів мотивації професійної самоефективності - успішність діяльності (Кревська, 2018).

Н. Лаптєва (2020) провела дослідження професійної самоефективності серед працівників українських комерційних підприємств та здійснила психометричну адаптацію методики «Шкала професійної самоефективності» (Schyns \& von Collani, 2002). Дослідниця показала, що перекладена українська версія характеризується високою конструктною валідністю. Встановлено високий рівень ретестової надійності шкали. При оцінці критеріальної валідності показано наявність взаємозв'язків між професійною самоефективністю, з одного боку, та залученістю і зовнішньою орієнтацією, 3 іншого (Лаптева, 2020).

Водночас слід наголосити, що професійна самоефективність персоналу освітніх організацій в українській психологічній науці раніше не виступала предметом спеціальних досліджень.

Отже, актуальність проблеми та іï недостатня розробленість дозволили сформулювати мету дослідження: здійснити теоретичний та емпіричний аналіз професійної самоефективності персоналу освітніх організацій.

\section{Завдання дослідження:}

1) На основі зарубіжної літератури визначити сутність професійної самоефективності та проаналізувати основні напрями досліджень професійної самоефективності персоналу організацій, зокрема освітніх.

2) Дослідити рівень розвитку професійної самоефективності персоналу освітніх організацій.

3) Проаналізувати особливості розвитку професійної самоефективності у персоналу освітніх організацій з різними соціально-демографічними та організаційно-професійними характеристиками.

4) Проаналізувати зв'язок між рівнем розвитку професійної самоефективності персоналу освітніх організацій й характеристиками його організації.

\section{Методика та організація дослідження.}

Для проведення дослідження використовувались теоретичні та емпіричні методи. Зокрема, був використаний теоретичний метод узагальнення та систематизації основних підходів в сучасній зарубіжній психології щодо дослідження професійної самоефективності.

Для емпіричного дослідження професійної самоефективності застосовувалась «Шкала професійної самоефективності (коротка версія)» («Short Occupational Self-Efficacy Scale») (Rigotti, Schyns \& Mohr, 2008), адаптація О. Креденцер (2020). Методика містить 6 питань та є скороченою версією «Шкали професійної самоефективності» (Schyns \& von Collani, 2002), яка складалась з 20 питань. «Шкала професійної самоефективності (коротка версія)» пройшла стандартизацію в п'яти країнах Європи (Німеччина, Швеція, Бельгія, Великобританія та Іспанія) та показала високу валідність щодо дослідження професійної самоефективності персоналу організацій.

Аналіз соціально-демографічних та організаційно-професійних характеристик здійснювався за допомогою спеціально розробленої анкети-паспортички.

Обробка результатів здійснювалась методами математичної статистики (описові статистики, кореляційний аналіз, дисперсійний аналіз (ANOVA)) за допомогою програми SPSS (22 версія). 
Дослідження проводилось в березні-червні 2020 року під час жорсткого карантину, пов'язаного 3 першою хвилею пандемії COVID-19.

Дослідження проведено в рамках виконання науково-дослідної теми лабораторії організаційної та соціальної психології Інституту психології імені Г.С. Костюка НАПН України «Психологоорганізаційні детермінанти забезпечення психологічного здоров'я персоналу освітніх організацій в умовах соціальної напруженості» (2019-2021рр.), науковий керівник -дійсний член НАПН України, доктор психологічних наук, професор Л. Карамушка.

Вибірка дослідження. У дослідженні взяли участь 473 працівники закладів загальної середньої освіти 3 різних регіонів України. Із них $12 \%$ - чоловіки, $88 \%$ - жінки; $76 \%$ - одружених, $24 \%$ неодружених. За віком опитані розподілились так: 11,4\% - до 30 років, 27,7\% - від 31 до 40 років, 34,3\% - від 41 до 50 років, і 26,6\% - понад 50 років.

За посадовим складом вибірка мала такий розподіл: $20,8 \%$ - педагогічні працівники початкової школи; 29,6\% - педагогічні працівники середньої школи; 24,5\% - педагогічні працівники старшої школи; 10,2\% - соціальні педагоги, $15 \%$ - керівники.

\section{Результати дослідження та їх обговорення.}

1) Професійна самоефективність персоналу освітніх організацій: зміст та основні напрями досліджень.

Концепт «професійна самоефективність» (occupational self-efficacy) був запроваджений зарубіжними психологами B. Schyns \& G. Von Collani (2002). Дослідники виходили, насамперед, з поглядів A. Bandura (1977), який стверджував, що в оцінці самоефективності важливо конкретизувати завдання, яке вирішується. Наприклад, коли дослідники хочуть дослідити конкретну діяльність, припустимо, написання наукової статті, вони повинні використовувати специфічну самоефективність, а саме самоефективність для написання наукової роботи. Отже, були розроблені інструменти, які окрім загальної самоефективності (Schwarzer, 1994; Shelton, 1990) оцінюють самоефективність в конкретній сфері (наприклад, Speier \& Frese, 1997) або самоефективність до певних завдань (наприклад, Kelly \& Nelson, 1999). Однак B. Schyns \& G. Von Collani (2002) стверджують, що в організаційних дослідженнях використання цього специфічного типу самоефективності має недоліки, адже виникають труднощі у порівнянні між працівниками в різних організаціях або між різними завданнями в одній організації. Концепт «професійної самоефективності» спрямований на вирішення цієї проблеми та визначається як переконаність людини у здатності успішно виконувати завдання, пов'язані з іiі роботою (Schyns \& von Collani, 2002). Професійна самоефективність, на думку B. Schyns, S. Sczesny (2010), є відносно стабільною завдяки своїм співвідношенням із характеристиками особистості. Водночас, як підкреслюють автори, професійну самоефективність можна вважати менш стабільною, ніж загальну самоефективність, адже на неї може легше впливати відповідний досвід. Концепт «професійної самоефективності» дозволяє здійснювати порівняння між різними типами робочих місць або професій, що робить його корисним для досліджень в організаційному контексті (Schyns \& Sczesny, 2010).

R. Alon, R.G. Cinamon \& D. Aram (2021) зазначають, що професійна самоефективність розглядається як віра людини у ії здатність успішно виконувати контекстуальні завдання у своїй роботі, як здатність наполегливо працювати і справлятися з викликами та труднощами, які виникають в процесі роботи. Підкреслено, що люди 3 високою професійною самоефективністю ставлять перед собою більш високі цілі, пов'язані з роботою, вкладають більше зусиль у свою кар'єру, є більш наполегливими у вирішенні завдань, пов'язаних із успіхом (Abele \& Spurk, 2009; Bandura, 1977).

Ми визначаємо професійну самоефективність персоналу освітніх організаиій як систему суб’єктивних уявлень про здатність успішно діяти в ситуаціях, пов'язаних з педагогічною діяльністю та 3 іншими професійними контекстами, яка має оцінюючий характер i забезпечує регуляцію дій, спрямованих на досягнення професійних цілей, за рахунок формування суджень про свою здатність успішно вирішити поставлені робочі завдання.

У зарубіжній психологічній науці проведено ряд досліджень професійної самоефективності в організаціях різних соціально-економічних сфер. Аналіз емпіричних досліджень показав, що основними психологічними показниками, що корелюють з професійною самоефективністю, $є$ :

- на особистісному рівні - емоційний інтелект, лідерські якості, інноваційність, готовність до змін, самооцінка, психічне здоров'я;

- на організаційному рівні - організаційна прихильність, кар‘єра, мотивація, задоволеність роботою, залученість до роботи, психологічні характеристики робочих завдань.

Розглянемо основні результати проведених досліджень.

Одним із суттєвих корелятів професійної самоефективності є емоційний інтелект персоналу організацій. 
Так, К. Thiripurasundari \& M. Kamini (2016) дослідили зв'язок професійної самоефективності та емоційного інтелекту серед жінок-керівників комерційних банків. Результати дослідження показали позитивну кореляцію між емоційним інтелектом та професійною самоефективністю. Окрім того, визначено, що емоційний інтелект та професійна самоефективність суттєво впливають на результати роботи як на індивідуальному, так і на організаційному рівнях. Дослідження показує важливість емоційного інтелекту та професійної самоефективності навіть для працівників, робота яких вимагає високої технічної чи наукової кваліфікації.

Зв'язок емоційного інтелекту та професійної самоефективності досліджували також N. Rathi \& R. Rastogi (2009). Основною метою цього дослідження було вивчення взаємозв'язку між емоційним інтелектом, професійною самоефективністю та організаційною прихильністю. Це дослідження показало, по-перше, позитивний зв'язок між емоційним інтелектом та загальною й професійною самоефективністю. Крім того, ця робота також підкреслює важливість професійної самоефективності в організаційному контексті. Так, доведено, що емоційний інтелект та професійна самоефективність персоналу організацій тісно пов'язані з відданістю персоналу своїм організаціям. Однією з ймовірних причин такого зв'язку може бути, на думку N. Rathi \& R. Rastogi (2009), те, що особи з високим емоційним інтелектом більш експертно оцінюють і контролюють свої емоції, в результаті чого вони відчувають більшу впевненість і контроль над виконаними завданнями, що, у свою чергу, посилює їх переконання в ефективності. Крім того, співробітники з вищою інтелектуальною активністю краще усвідомлюють себе з точки зору своїх здібностей та обмежень, що також сприяє високому рівню їх самоефективності.

C. Guarnaccia, F. Scrima, A. Civilleri et al. (2018) дослідили взаємозв'язок між залученням до роботи, задоволеністю роботою та здоров'ям персоналу організацій. Виявлено, що працівники 3 тимчасовою зайнятістю демонструють нижчий рівень задоволеності роботою та загальний стан здоров'я, ніж постійні працівники. 3 іншого боку, було розглянуто професійну самоефективність як особистісний ресурс, тобто як посередницьку змінну між задоволеністю роботою, типом зайнятості (тимчасова чи постійна) та загальним станом здоров'я. Відповідно до отриманих результатів, постійна робота має прямий зв'язок із високою професійною самоефективністю, задоволеністю роботою та загальним станом здоров'я. Водночас висока професійна самоефективність здійснює прямий вплив на більш високий рівень залученості до роботи, задоволеність роботою та загальний стан здоров'я.

Значний внесок у дослідження корелятів професійної самоефективності внесла В. Schyns (2004). Зокрема, дослідниця побудувала модель впливу професійної самоефективності на готовність до організаиійних змін. Вона визначила, що професійна самоефективність впливає на готовність до організаційних змін на трьох етапах. На першому етапі (до організаційних змін) самоефективність впливає на готовність до змін, оскільки вона є певним «підсилювачем» для навчання новим видам діяльності, пов'язана $з$ відкритістю до організаційних змін та розвитком. На другому етапі (під час організаційних змін) співробітники з високою професійною самоефективністю будуть більш стійкими, коли зустрінуться 3 перешкодами у своїх нововведеннях, i будуть витрачати більше зусиль, щоб їх подолати. На третьому етапі (після організаційних змін) працівники з високою самоефективністю легше адаптуються до цих змін, ніж працівники з низькою самоефективністю. Вони також витрачають більше зусиль на побудову наступних нових завдань.

У свою чергу, зазначає В. Schyns (2004), самоефективність впливає на готовність працівників до професійних змін на різних етапах організаційних змін. У цьому сенсі готовність до професійних змін, на думку авторки, означає готовність братися за виконання завдань 3 вищими вимогами, ніж зараз. Ця готовність пов'язана з самоефективністю, оскільки працівники з високою самоефективністю більш охоче беруться за більш складні завдання. Їх самоефективність змушує їх припустити, що вони можуть успішно виконати завдання, і тому вони не тільки візьмуться за ці завдання, але й зберігаються довше у своєму виконанні, якщо їм це не вдається відразу (Schyns, 2004).

Достатньо велику кількість робіт присвячено аналізу звязку професійної самоефективності та лідерства (Hentrich, Zimber, Garbade, Gregersen, Nienhaus \& Petermann, 2017; Schyns \& Sczesny, 2010 та ін.).

Лідерство впливає на самоефективність за допомогою процесів, запропонованих А. Бандурою (1977): лідери можуть надати своїм підлеглим можливість опанувати досвід. Вони можуть служити взірцем і заохочувати своїх підлеглих за допомогою вербального переконання. Отже, підтримка керівництва $\epsilon$ важливою для самоефективності працівників на всіх етапах змін.

Досить цікавою роботою в контексті аналізу професійної самоефективності $є$ дослідження D. Terry, B. Peck, A. Smith \& H. Nguyen (2019), проведене серед медсестр. Дослідники проаналізували рівень загальної та професійної самоефективності медсестр, їі зв'язок з психологічним капіталом та 
соціально-демографічними характеристиками медсестр. Виявлено, що поряд 3 досить високим рівнем загальної самоефективності рівень професійної самоефективності у медсестр значно нижчий. Окрім того, встановлено значні відмінності щодо рівня розвитку професійної самоефективності медсестр між віковими групами, рівнем навчання, місцем, де вони виросли. Так, було підкреслено, що столичні медсестри мають значно вищий рівень як загальної, так і професійної самоефективності у порівнянні зі своїми колегами у сільській місцевості. Більше того, було виявлено, що чим більш віддалене від міських районів місце виховання, тим більша ймовірність того, що вони будуть демонструвати нижчий рівень загальної та професійної самоефективності. Крім того, було показано, що на рівень загальної та професійної самоефективності медсестр впливає їх вік. Старші медсестри з більш високим рівнем ефективності, надією, оптимізмом та нижчим рівнем доходу продемонстрували більш високий рівень загальної та професійної самоефективності (Terry, Peck, Smith \& Nguyen, 2019).

Досліджуючи кореляцію між загальною та професійною самоефективністю, було показано, що рівень кореляції між кожним показником був значно вищим у молодших вікових групах. В цілому результати дослідження показують, що молодші медсестри, які мають сільське походження та які ще продовжують навчання, частіше мають вищий рівень загальної та професійної самоефективності, якщо вони мають більш високий рівень психологічного капіталу (Terry, Peck, Smith \& Nguyen, 2019).

Певні аспекти дослідження професійної самоефективності персоналу організацій в зарубіжній літературі знайшли відображення і в сфері освіти.

P. Runhaar, T. Bednall, K. Sanders \& H. Yang (2016) дослідили зв'язок професійної самоефективності та інноваційної поведінки вчителів загальноосвітніх навчальних закладів. Дослідники розглядають інноваційну поведінку як ризиковану, оскільки вона передбачає невизначеність і ризик невдачі та можливу критику 3 боку колег. Виходячи 3 того, що професійна самоефективність визначається як переконання, що індивід може впоратися з труднощами, з якими він стикається у своїй роботі, вона може сприяти подоланню цих ризиків. Дослідники зазначають, що коли підвищується професійна самоефективність вчителів, це посилює їх залучення до інновацій, оскільки люди з високою самоефективністю, швидше за все, вірять, що інноваційні ідеї, які вони вносять, будуть оцінені іншими. Більше того, якщо вони не знайдуть підтримки своїх ідей, це не суттєво вплине на імідж людей 3 високою самоефективністю, оскільки високоефективні люди частіше вважають, що вони можуть покращити себе власними зусиллями. Крім того, наголошено, що співробітники з високою професійною самоефективністю часто є ефективними менеджерами щодо управління конфліктами. Отже, опір вчителів, який може супроводжувати інноваційні зміни в освітніх організаціях, швидше за все, не відштовхне високоефективних працівників від впровадження інновацій.

R. Alon \& C. Aram (2021) провели дослідження серед шкільних консультантів та визначили опосередкований вплив професійної самоефективності на зв язок між характеристиками їх роботи та задоволеністю роботою, задоволеністю життям та кар'єрою. Дослідники довели, що такі характеристики роботи шкільних консультантів як підтримка, чіткість завдань та автономія значно підвищують їх професійну самоефективність, яка, натомість, позитивно впливає на їх задоволеність роботою, задоволеність життям та кар'єру.

Ще одним важливим напрямом досліджень професійної самоефективності в сфері освіті $\epsilon$ дослідження, що стосуються зв'язку професійної самоефективності та різних аспектів психічного здоров’я, зокрема професійного вигорання, стресу, психологічного благополуччя тощо.

Так, наприклад, F. Salimirad \& N. Srimathi (2016) встановили значний позитивний зв'язок між психологічним благополуччям та професійною самоефективністю вчителів.

Особливо важливого значення цей напрям досліджень набуває під час пандемії, пов'язаної 3 COVID-19. Адже в ряді досліджень в межах організаційної психології встановлено негативний вплив пандемії на роботу організацій та персоналу (Giorgi et al., 2020; Kniffi et al., 2021). Що стосується освітніх організацій, то тут карантинні обмеження торкнулися всіх, без виключення, організацій сфери освіти (дистанційне навчання, віддалена робота, зміна режиму роботи тощо), що суттєво позначилося на діяльності персоналу освітніх організацій.

Організація Об'єднаних Націй з питань освіти, науки та культури (ЮНЕСКО) визначила розгубленість вчителів та стрес як один із несприятливих наслідків карантинних обмежень, через невизначеність щодо їх тривалості та відсутності знань щодо особливостей дистанційної освіти. Невизначеність щодо тривалості соціальної ізоляції призвела до виснаження та інших симптомів синдрому вигорання вчителів, що сприяло зменшенню впевненості в їх здатності виконувати свою роботу та керувати поведінкою учнів (Kim \& Buric', 2020).

Особливо тривожним результатом вигорання вчителя $є$ його негативний вплив на самоефективність вчителя (Herman, Hickmon-Rosa \& Reinke, 2018). 
3 іншого боку, деякі вчителі займають позицію стійкості у боротьбі з чинниками вигорання, що, у свою чергу, може мінімізувати або послабити стресові ситуації та конфлікти, використовуючи спеціальні навички, що застосовуються для вирішення проблем, таким чином оптимізуючи самоефективність організації (Grayson \& Alvarez, 2008).

Деякі дослідники досліджували зв'язок між синдромом вигорання та професійною самоефективністю, зазначаючи, що вчителі, які вважають себе менш компетентними в управлінні та впровадженні дисципліни в класі, повідомили про вищий рівень вигорання, ніж вчителі з більш високим рівнем самоефективності (Shoji, Cieslak, Smoktunowicz, Rogala, Benight, Luszczynska, 2016; Friedman,Farber, 1992).

H. Pereira, V. Gonçalves \& R. Assis (2021) встановили негативний зв'язок між професійною самоефективністю бразильських вчителів та всіма симптомами професійного вигорання (виснаження, психічна відстороненість, емоційні порушення, когнітивні порушення та загальний рівень вигорання). Зокрема, змінні, пов'язані з синдромом вигорання, негативно корелювали 3 самооцінкою, тоді як професійна самоефективність показала позитивний кореляційний зв'язок із самооцінкою, що вказує, на думку дослідників, на те, що вчителі, які мали вищу самооцінку, відчували менше симптомів вигорання, тоді як виявляли більш високий рівень професійної самоефективності.

Суттєве значення в контексті досліджень професійної самоефективності відіграють розробки валідних інструментів ї̈ вимірювання.

Сьогодні вже розроблено розроблено кілька інструментів для вимірювання професійної самоефективності:

1) Шкала самоефективності роботи (Work Self-Efficacy Scale - WSES) (Pepe, Avallone \& Porcelli, 2007);

2) Шкала самоефективності в професійній діяльності (Self-Efficacy in Occupational Activities Scale - SOAS) (Nunes \& Noronha, 2011);

3) Шкала професійної самоефективності (Occupational Self-Efficacy Scale- OSS) (Schyns \& von Collani, 2002);

4) Шкала професійної самоефективності (коротка форма) (Short Occupational Self-Efficacy ScaleOSS-SF) (Rigotti et al., 2008).

Зокрема, OSS (в оригінальній та короткій формі) застосовується у всьому світі (Rigotti et al., 2008). Оскільки дослідницькі інструменти, що використовуються в професійних умовах, повинні бути короткими, щоб забезпечити ефективну процедуру збору даних, Schyns and von Collani (2002) розробили відповідну зменшену версію OSS лише з вісьмома пунктами. Згодом Rigotti та ін. (2008) зменшили обсяг опитувальника 3 восьми пунктів до версії із шести пунктів та довели іï високу валідність. OSS-SF пропонує ряд переваг перед іншими існуючими шкалами професійної самоефективності. По-перше, це найменша шкала, розроблена для оцінки цього конструкту. Він складається з єдиного виміру для оцінки професійної самоефективності із загальними елементами професійної самоефективності, що дозволяє використовувати його в різних професійних умовах. Ця перевага особливо актуальна з огляду на різні форми роботи в сучасному світі (Damásio, Pizarro de Freitas \& Koller, 2014).

2) Рівень розвитку професійної самоефективності персоналу освітніх організацій.

Для виконання другого завдання дослідження проаналізуємо, насамперед, рівень розвитку професійної самоефективності персоналу освітніх організацій.

Як видно із таблищі 1 , професійна самоефективність відповідає рівню вище середнього $(\mathrm{M}=26,41, \mathrm{SD}=4,17)$.

Таблиия 1

Рівень розвитку професійної самоефективності персоналу освітніх організацій

\begin{tabular}{|c|c|c|c|c|}
\hline Види самоефективності & Мінімум & Максимум & $\begin{array}{c}\text { Середнс } \\
\text { значення }\end{array}$ & $\begin{array}{c}\text { Стандартне } \\
\text { відхилення }\end{array}$ \\
\hline Професійна самоефективність & 13,00 & 36,00 & 26,41 & 4,17 \\
\hline
\end{tabular}

На рисунку 1 представлені результати, що стосуються кількісного розподілу освітян за рівнями розвитку професійної самоефективності. Як свідчать отримані дані щодо професійної самоефективності, то тут спостерігається подібна ситуація: на високому рівні професійна самоефективність представлена у $15,7 \%$ персоналу освітніх організацій, на середньому - у 63,5\%, на низькому - у 20,8\%. 


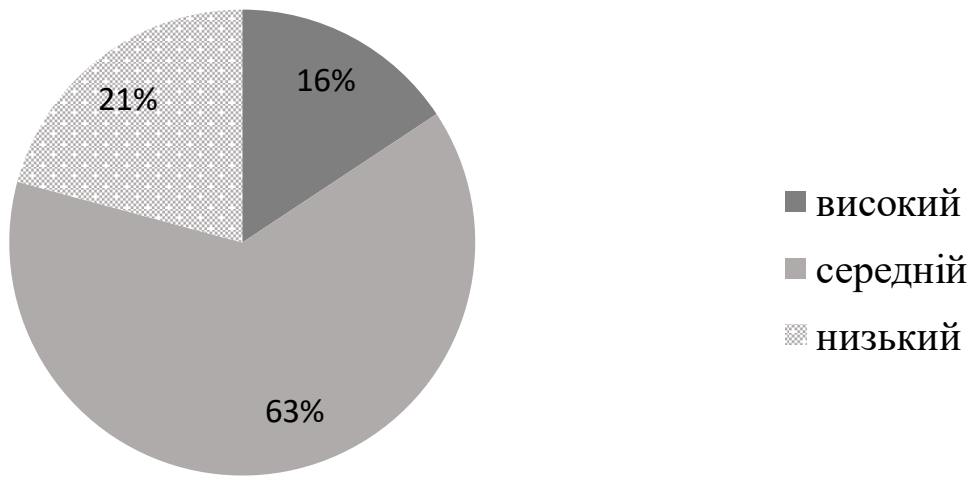

Рис. 1. Рівні розвитку професійної самоефективності персоналу освітніх організацій (у \% до загальної кількості опитаних)

Отже, на наш погляд, на основі отриманих даних ми можемо констатувати, що у освітян спостерігається недостатній рівень розвитку їх переконаності у здатності успішно виконувати завдання, пов'язані з їх роботою.

Це може проявлятися в деяких ускладненнях, пов'язаних 3 плануванням діяльності, недостатньою наполегливістю, невпевненістю, небажанням долати труднощі як у вирішенні професійних завдань, так і в побудові соціальних контактів. Проблемним місцем виступає значний відсоток респондентів з низьким та середнім рівнями професійної самоефективності.

Отримані дані дещо перетинаються з результатами дослідження професійної самоефективності серед бразильських вчителів (Pereira, Gonçalves \& Assis, 2021), які показали високий та низький рівень професійної самоефективності на рівні 21,5\%, а середній - у $57 \%$.

3) Особливості розвитку професійної самоефективності у персоналу освітніх організацій 3 різними соціально-демографічними та організаційно-професійними характеристиками.

Для виконання третього завдання дослідження нами було визначено встановити зв'язок між рівнем розвитку професійної самоефективності персоналу освітніх організацій та їхніми організаційнопрофесійними (освітньо-стажевими, посадово-кваліфікаційними) й соціально-демографічними характеристиками.

Проаналізуємо, насамперед, зв'язок з освітньо-стажевими характеристиками. Як свідчать отримані дані (таблиця 2), стаж на посаді позитивно корелює із професійною само ефективністю $(\mathrm{r}=0,143 ; \mathrm{p}<0,01)$. Тобто досвід роботи на певній посаді сприяє підвищенню впевненості педагогів у здатності успішно виконувати завдання, пов'язані зїхньою роботою.

Ці дані збігаються 3 даними С. Казакової (2018), в дослідженнях якої встановлено, що зі збільшенням стажу керівників закладів професійно-технічної освіти показники самоефективності $\epsilon$ меншими, особливо у жінок.

Табличя 2

Зв'язок між рівнем розвитку самоефективності персоналу освітніх організацій та його освітньо-стажевими характеристиками, (r)

\begin{tabular}{|c|c|c|c|}
\hline \multirow{2}{*}{ Види самоефективності } & \multicolumn{3}{|c|}{ Освітньо-стажеві характеристики } \\
\cline { 2 - 4 } & посада & стаж на посадi & рівень освіти \\
\hline Професійна самоефективність & $\underline{-0,132^{* *}}$ & $\underline{0,143^{* *}}$ & $-0,073$ \\
\hline
\end{tabular}

$* * \mathrm{p}<0,01$;

Окрім того, відсутній статистично значущий зв'язок між рівнем розвитку самоефективності персоналу освітніх організацій та рівнем й типом його освіти.

Що стосується посадово-кваліфікаційних характеристик персоналу освітніх організацій, то, як свідчать дані таблищі 3, існує статистично значущий зв'язок між професійною самоефективністю та посадою працівників освітніх організацій $(\mathrm{p}<0,01)$. Причому, спостерігається зворотний зв'язок із професійною самоефективністю персоналу освітніх організацій. 
Для більш детального аналізу зв'язку між посадою освітян та рівнем їх самоефективності нами було здійснено дисперсійний аналіз (ANOVA), результати якого також показали наявність зв'язку між посадою та професійною самоефективністю $(\mathrm{F}=2,89 ; \mathrm{p}<0,05)$. Як видно із рисунка 2, рівень професійної самоефективності у психологів значно нижчий, ніж у педагогів та керівників. На наш погляд, це можна пояснити тим, що під час карантину (особливо під час першої хвилі 2020 року) професійні завдання шкільних психологів (зміст, регламент, умови, принципи тощо) були взагалі не визначені, що могло позначитися на зниженні впевненості у можливості їх виконувати.

Отримані дані щодо загальної самоефективності частково співпадають 3 даними О. Бондарчук (2018). Дослідниця встановила, що у керівників закладів освіти соціальна самоефективність $є$ вищою порівняно $з$ працівниками, особливо чітко така тенденція виявляється у педагогічних працівників жіночої статі.

Результати дослідження не встановили зв'язку між професійною самоефективністю та соціальнодемографічними характеристиками персоналу освітніх організацій.

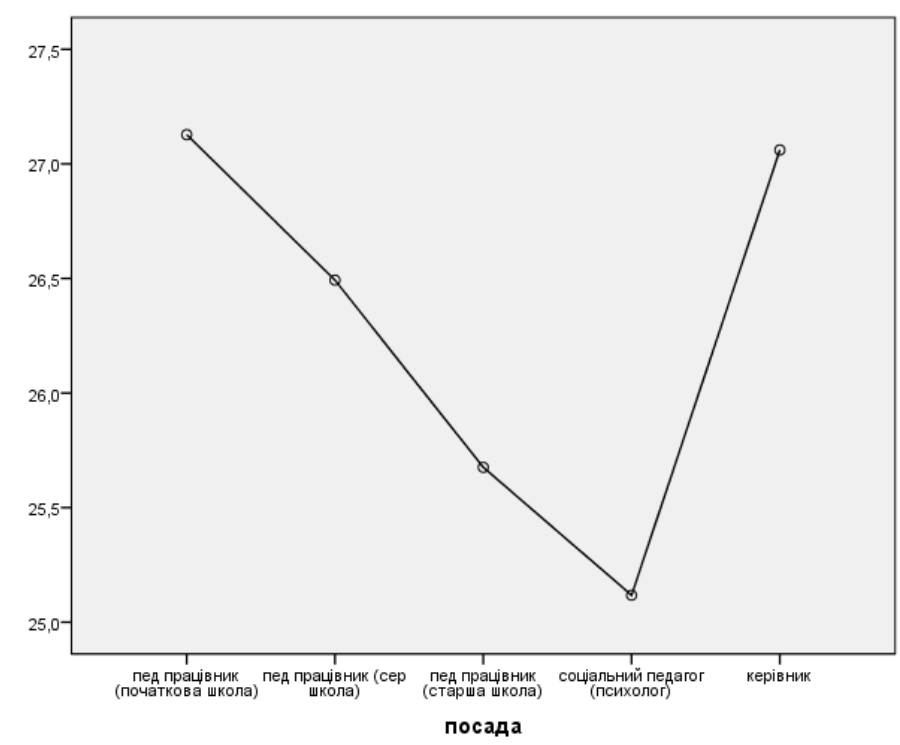

Рис. 2. Рівень розвитку професійної самоефективності персоналу освітніх організацій в залежності від його посади

4) Зв'язок мізс рівнем розвитку професійної самоефективності персоналу освітніх організацій й характеристиками ӥхніх організації.

Для виконання четвертого завдання дослідження нами було проаналізовано вплив характеристик організаиії на рівень розвитку професійної самоефективності персоналу освітніх організацій.

Табличя 3

Зв'язок між рівнем розвитку самоефективності персоналу освітніх організацій та характеристиками організацій, (r)

\begin{tabular}{|c|c|c|c|}
\hline \multirow{2}{*}{ Види самоефективності } & \multicolumn{3}{|c|}{ Характеристики організації } \\
\cline { 2 - 4 } & $\begin{array}{c}\text { Кількість осіб в } \\
\text { організації }\end{array}$ & Вік організаціï & $\begin{array}{c}\text { Місце розташування } \\
\text { організації }\end{array}$ \\
\hline Професійна самоефективність & $-0,060$ & $\underline{-0,116^{*}}$ & 0,018 \\
\hline
\end{tabular}

$* \mathrm{p}<0,05 ; * * \mathrm{p}<0,01 ; * * * \mathrm{p}<0,001$

Отримані дані свідчить про те, що існує зворотний статистично значущий зв'язок між віком організації та професійною самоефективністю $(\mathrm{r}=-0,116 ; \mathrm{p}<0,05)$ (таблиия 3). Наявність цього зв'язку свідчить про те, що у великих (за кількістю працівників) освітніх організаціях рівень професійної самоефективності нижчий, ніж у нечисленних (за кількістю працівників) організаціях. 


\section{Висновки.}

1) Професійну самоефективність персоналу освітніх організацій можна визначити як систему суб'єктивних уявлень про здатність успішно діяти в ситуаціях, пов'язаних з педагогічною діяльністю, та 3 іншими професійними контекстами, яка має оцінюючий характер і забезпечує регуляцію дій, спрямованих на досягнення професійних цілей, за рахунок формування суджень про свою здатність успішно вирішити поставлені робочі завдання.

2) Основними психологічними показниками, що корелюють 3 професійною самоефективністю, $€$ : на особистісному рівні - емоційний інтелект, лідерські якості, інноваційність, готовність до змін, самооцінка, психічне здоров'я; на організаційному рівні - організаційна прихильність, кар“єра, мотивація, задоволеність роботою, залученість до роботи, психологічні характеристики робочих завдань.

3) Спостерігається недостатній рівень розвитку професійної самоефективності персоналу освітніх організацій.

4) Рівень професійної самоефективності у психологів нижчий, ніж у педагогів та керівників. Досвід роботи на певній посаді сприяє підвищенню впевненості педагогів у здатності успішно виконувати завдання, пов’язані зїхньою роботою.

5) У великих (за кількістю працівників) освітніх організаціях рівень професійної самоефективності нижчий, ніж у нечисленних (за кількістю працівників) організаціях.

6) Отримані дані свідчать про необхідність розробки спеціальних психологічних технологій щодо розвитку різних видів самоефективності з урахуванням встановлених закономірностей.

Перспективи подальших досліджень ми вбачаємо у дослідженні особливостей розвитку різних видів самоефективності персоналу освітніх організацій в залежності від їх особистісних характеристик, а також у вивченні психологічних характеристик освітньої організації, які можуть впливати на рівень розвитку самоефективності їі працівників.

\section{Література}

1.Бондарчук, O.I. (2018). Соціальна самоефективність працівників як чинник психологічної безпеки середовища. Збірник наукових статей міжнародного університету й Інституту сочіальної та політичної психології НАПН України. Серія: «Психологічні науки: проблеми $і$ здобутки», 2(12), 5-24.

2.Казакова, С.В. (2018). Особливості самоефективності керівників закладів професійно-технічної освіти як психологічного чинника успішності їхньої професійної діяльності. Вісник післядипломної освіти. Серія: Соціальні та поведінкові науки, 6, 65-77.

3.Кревська О. (2018). Мотиваційні чинники професійної самоефективності особистості. дис.... канд. психол. наук. Луцьк 4.Креденцер, О. (2016). Підприємницька самоефективність персоналу освітніх організацій як чинник розвитку їх підприємницької активності. Організачійна психологія. Економічна психологія, 1(4), 51-60.

5.Креденцер, О. (2019). Психологія розвитку підприємницької активності персоналу освітніх організацій : монографія.

6.Кузнецова, А.А. \& Никишина, В.Б. (2018). Менеджмент высшей школы: самоэффективность и удовлетворенность профессиональной деятельностью преподавателей высшей школы административного сектора. Иннов: электронный научный журнал, 4 (37).URL: http://www.innov.ru/science/economy/menedzhment-vysshey-shkoly-samoeffe/

7.Лаптєва, Н. (2020). Психометричний аналіз української версії шкали професійної самоефективності. Психологічний часопис, 6(2), 164-172. https://doi.org/10.31108/1.2020.6.2.15

8.Линенко, А. (2019). Професійна самоефективність як педагогічна проблема. Науковий вісник Південноукраїнського національного педагогічного університету імені К. Д. Уиинського, Вип 1 (126). Серія: Педагогіка, 66-69.

9.Музика, О. О. (2020). Психологічна методика «Профіль професійної самоефективності студентів (ППСС)» (Авторське свідоцтво о 100028). Мінекономіки.

10. Музика, О.О. (2018). Самоефективність як фактор професіоналізації студентів. Освітологічний дискурс,3-4 (22-23), 83-94.

11. Abele, A. E. \& Spurk, D. (2009). The longitudinal impact of self-efficacy and career goals on objective and subjective career success. Journal of Vocational Behavior, 74, 53-62.

12. Alon, R., Cinamon, R.G., \& Aram, D. (2021). Working adults' future occupational plans: the contribution of role characteristics, social support, and occupational self-efficacy. Int. J. Educ. Vocat. Guid., 24, 1-21. doi: 10.1007/s10775-02109496-X.

13. Bandura, A. (1977). Self-efficacy: Toward a unifying theory of behavioral change. PsychologicalReview, 84, $191-215$.

14. Damásio, B.,Pizarro de FreitasC.\&KollerS. (2014). Occupational Self-Efficacy Scale - Short Form (OSS-SF): Adaptation and evidence of construct validity of the Brazilian version. Revista Brasileira de Orientação Profissional,15, 65-74.

15. Friedman, I.A.\& Farber, B.A. (1992). Professional self-concept as a predictor of teacher burnout. J. Educ. Res., 86, $28-35$.

16. Giorgi, G., Lecca, L. I., Alessio, F., Finstad, G. L., Bondanini, G., Lulli, L. G., Arcangeli, G.\&Mucci, N. (2020). COVID19-Related Mental Health Effects in the Workplace: A Narrative Review. Int. J. Environ. Res. Public Health, 21 : 7857. https://doi.org/10.3390/ijerph17217857

17. Grayson, J.L. \& Alvarez, H.K. (2008). School climate factors relating to teacher burnout: A mediator model.Teach. Educ., 24,1349-1363. 
18. Grau, R., Salanova, M., \& Peiró, J. M. (2001). Moderating effects of self-efficacy on occupational stress. Spanish Journal of Psychology, 5, 63-74.

19. Guarnaccia, C., Scrima, F., Civilleri, A. et al (2018). The Role of Occupational Self-Efficacy in Mediating the Effect of Job Insecurity on Work Engagement, Satisfaction and General Health. Curr Psychol 37, 488-497. https://doi.org/10.1007/s12144016-9525-0

20. Hentrich, S., Zimber, A., Garbade, S. F., Gregersen, S., Nienhaus, A., \& Petermann, F. (2017). Relationships between transformational leadership and health: The mediating role of perceived job demands and occupational self-efficacy. International Journal of Stress Management, 24(1), 34-61.

21. Herman, K.C., Hickmon-Rosa, J.E., \& Reinke, W.M. (2018). Empirically derived profiles of teacher stress, burnout, selfefficacy, and coping and associated student outcomes. J. Posit. Behav. Interv., 20, 90-100.

22. Judge, T. A., \& Bono, J. E. (2001). Relationship of core self-evaluations trait-self-esteem, generalized self-efficacy, locus of control, and emotional stability-with job satisfaction and job performance: A meta-analysis. Journal of Applied Psychology, 86, 80-92.

23. Kelly, K. R., \& Nelson, R. C. (1999). Task-Specific Occupational Self-Efficacy Scale: A predictive validity study. JournalofCareerAssessment, 7, 381-392.

24. Kim,L.E., \& Buric',I.(2020). Teacherself-efficacyandburnout:Determiningthedirectionsofpredictionthroughanautoregressive cross-lagged panel model. J. Educ. Psychol. 112, 1661-1676.

25. Kniffin, K. M., Narayanan, J., Anseel, F., Antonakis, J., Ashford, S. P., Bakker, A. B., . . \&Vugt, M. v. (2021). COVID-19 and the workplace: Implications, issues, and insights for future research and action. American Psychologist, 76(1), 63-77. http://dx.doi.org/10.1037/amp0000716

26. Nunes, M. F. O., \& Noronha, A. P. P. (2011). Escala de autoeficácia para atividades ocupacionais: Estudo da estrutura interna e precisão. Avaliação psicológica, 10(1), 25-40.

27. Pepe, S., Farnese, M., Avalone, F., \& Vecchione, M.(2010). Work Self-Efficacy Scale and Search for Work Self-Efficacy Scale: A Validation Study in Spanish and Italian Cultural Contexts.Revista de Psicología del Trabajo y de las Organizaciones, 3 , 201- 210

28. Pereira, H., Gonçalves, V.O., \& Assis, R.M.d. (2021). Burnout, Organizational Self-Efficacy and Self-Esteem among Brazilian Teachers during the COVID-19 Pandemic. Eur. J. Investig. Health Psychol. Educ., 11, $795-803$. https://doi.org/10.3390/ejihpe11030057

29. Runhaar, P., Bednall, T., Sanders, K., \& Yang, H. (2016) Promoting VET teachers' innovative behaviour: exploring the roles of task interdependence, learning goal orientation and occupational self-efficacy. Journal of Vocational Education \& Training, 68:4, 436-452, DOI: 10.1080/13636820.2016.1231215

30. Rathi, N. \& Rastogi, Renu. (2009). Assessing The relation ship between emotional intelligence, occupational selfefficacy and organizational commitment. Journal of the Indian Academy of Applied Psychology. 35. 93-102.

31. Rigotti, T., Schyns, B., \& Mohr, G. (2008). A Short Version of the Occupational Self-Efficacy Scale: Structural and Construct Validity Across Five Countries. Journal of Career Assessment, 16(2), 238255.https://doi.org/10.1177/1069072707305763

32. Salimirad, Fatemeh \& Srimathi, N. (2016). The Relationship between, Psychological Well-Being and Occupational SelfEfficacy among Teachers in the City of Mysore, India. International Journal of Indian Psychology. 3. 10.25215/0302.037.

33. Schyns, B. (2004). The Influence of Occupational Self-Efficacy on the Relationship of Leadership Behavior and Preparedness for Occupational Change. Journal of Career Development, 30(4), 247261. https://doi.org/10.1177/089484530403000402

34. Schyns, B., \& von Collani, G. (2002). A new Occupational Self-Efficacy Scale and its relation to personality constructs and organizational variables. European Journal of Work and Organizational Psychology, 11, 219-241.

35. Schyns, B., Sczesny, S. (2010). Leadership attributes valence in self-concept and occupational self-efficacy. Career development international, 15 (1). 78-92.

36. Shelton, S.H. (1990). Developing the construct of general self-efficacy. Psychological Reports, 66, 987-994.

37. Shoji, K., Cieslak, R., Smoktunowicz, E., Rogala, A., Benight, C.C., \& Luszczynska, A. (2016). Associations between job burnout and self-efficacy: A meta-analysis. Anxiety Stress Coping, 29, 367-386.

38. Slovak, G. (2010). Pre-Service Teacher Self-Efficacy: Theoretical and Research Considerations. The New Educational Review, 2010, 21, 17-30.

39. Speier, C., \& Frese, M. (1997). Generalized self-efficacy as a mediator and moderator between control and complexity at work and personal initiative: A longitudinal field study in East Germany. Human Performance, 10,171-192.

40. Stajkovic, A. D., \& Luthans, F. (1998). Self-efficacy and work-related performance: A meta-analysis.Psychological Bulletin, 124, 240-261.

41. Schwarzer, R. (1994). Optimistische Kompetenzerwartung: Zur Erfassung einer personellen Bewältigungsressource [Generalizedself-efficacy: Assessment of a personal copingresource]. Diagnostica, 40, 105-123.

42. Terry, D., Peck, B., Smith, A., \& Nguyen, H. (2019). Occupational Self-Efficacy and Psychological Capital Amongst Nursing Students: A Cross Sectional Study Understanding the Malleable Attributes for Success. European Journal of Investigation in Health, Psychology and Education, 10(1), 159-172. MDPI AG. Retrieved from http://dx.doi.org/10.3390/ejihpe10010014

43. Thiripurasundari, K., \& Kamini, M. (2016) Impact of emotional intelligence on occupational self-efficacy among women executives: an empirical study in banking industry. Shanlax International Journal of Management, 4 (2), 101-110.

44. United Nations Educational, Scientific and Cultural Organization (UNESCO). COVID-19 Educational Disruption and Response;UNESCO: Paris, France, 2020. 


\section{References}

1.Bondarchuk, O. I. (2018). Sotsialna samoefektyvnist pratsivnykiv yak chynnyk psykhologichnoï bezpeky seredovyscha [Employees' social self-efficacy as a factor in the psychological safety of the environment]. Zbirnyk naukovykh statei mizhnarodnogo universytetu i Instytutu sotsialnoi ta politychnoi psykhologii NAPN Ukrainy. Seria: «Psykhologichni nauky: problemy i zdobutky», 2(12),5-24. [in Ukrainian]

2.Kazakova, S. V. (2018). Osoblyvosti samoefektyvnosti kerivnykiv zakladiv profesiino-tekhnichnoiosvity yak psykhologichnogo chynnyka uspishnosti yikhnoi profesiinoi dialnosti [Features of self-efficacy of heads of vocational schools as a psychological factor in their professional efficiency]. Visnyk pislyadyplomnoi osvity. Seria: Sotsialni ta povedinkovi nauky, 6 , 65-77. [in Ukrainian]

3.Krevska, O. (2018). Motyvatsiini chynnyky profesiinoi samoefektyvnosti osobystosti [Motivational factors in professional selfefficacy of the individual]. dys.... kand. psykhol. nauk. Lutsk [in Ukrainian]

4.Kredentser, O. (2016). Pidpryyemnytska samoefektyvnist personalu osvitnikh organizatsii yak chynnyk rozvytku yikh pidpryyemnytskoi aktyvnosti [Entrepreneurial self-efficacy of the staff of educational organizations as their entrepreneurial activity factor]. Organizatsiina psykhologia. Ekonomichna psykhologia, 1(4), 51-60. [in Ukrainian]

5.Kredentser, O. (2019). Psykhologia rozvytku pidpryyemnytskoi aktyvnosti personalu osvitnikh organizatsii [Psychology of development of entrepreneurial activity of the staff of educational organizations]. [in Ukrainian]

6.Kuznetsova, A. A., \& Nikishina, V. B. (2018). Menedzhment vysshei shkoly: samoeffektivnost i udovletvorennost professionalnoi deyatelnostyu prepodavatelei vysshei shkoly administrativnogo sektora [Higher education management: selfefficacy and professional satisfaction of administrative sector higher education teachers]. Innov: elektronnyi nauchnyi zhurnal, 4(37). http://www.innov.ru/science/economy/menedzhment-vysshey-shkoly-samoeffe/ [in Russian]

7.Laptyeva, N. (2020). Psykhometrychnyi analiz ukrainskoi versii shkaly profesiinoi samoefektyvnosti [Psychometric analysis of the Ukrainian version of the Professional Self-Efficacy Scale]. Psykhologichnyi chasopys, 6(2), 164-172. https://doi.org/10.31108/1.2020.6.2.15 [in Ukrainian]

8.Lynenko, A. (2019). Profesiina samoefektyvnist yak pedagogichna problema [Professional self-efficacy as a pedagogical problem]. Naukovyŭ visnyk Pivdennoukraïnskogo natsionalnogo pedagogichnogo universytetu imeni K. D. Ushynskogo, Vyp 1(126). Seria: Pedagogika, 66-69. [in Ukrainian]

9.Muzyka, O. O. (2020). Psykhologichna metodyka «Profil profesiinoi samoefektyvnosti studentiv (PPSS)» (Avtorske svidotstvo No 100028) [Psychological assessment instrument «Profile of Students' Professional Self-Efficacy (PSSE)» (Author's certificate No. 100028)]. Minekonomiky. [in Ukrainian]

10. Muzyka, O. O. (2018). Samoefektyvnist yak faktor profesionalizatsii studentiv [Self-efficacy as a students' professionalization factor]. Osvitologichnyi dyskurs,3-4(22-23), 83-94. [in Ukrainian]

11. Abele, A. E., \& Spurk, D. (2009). The longitudinal impact of self-efficacy and career goals on objective and subjective career success. Journal of Vocational Behavior, 74, 53-62.

12. Alon, R., Cinamon, R.G., \& Aram, D. (2021). Working adults' future occupational plans: the contribution of role characteristics, social support, and occupational self-efficacy. Int. J. Educ. Vocat. Guid., 24, 1-21. https://doi.org/10.1007/s10775021-09496-x.

13. Bandura, A. (1977). Self-efficacy: Toward a unifying theory of behavioral change. Psychological Review, 84, $191-215$.

14. Damásio, B., Pizarro de Freitas, C., \& Koller, S. (2014). Occupational Self-Efficacy Scale - Short Form (OSS-SF): Adaptation and evidence of construct validity of the Brazilian version. Revista Brasileira de Orientação Profissional, 15, 65-74.

15. Friedman, I. A., \& Farber, B. A. (1992). Professional self-concept as a predictor of teacher burnout. J. Educ. Res., 86, $28-35$.

16. Giorgi, G., Lecca, L. I., Alessio, F., Finstad, G. L., Bondanini, G., Lulli, L. G., Arcangeli, G., \& Mucci, N. (2020). COVID19-Related Mental Health Effects in the Workplace: A Narrative Review. Int. J. Environ. Res. Public Health, 21 : 7857. https://doi.org/10.3390/ijerph17217857

17. Grayson, J. L., \& Alvarez, H. K. (2008). School climate factors relating to teacher burnout: A mediator model. Teach. Educ., 24, 1349-1363.

18. Grau, R., Salanova, M., \& Peiró, J. M. (2001). Moderating effects of self-efficacy on occupational stress. Spanish Journal of Psychology, 5, 63-74.

19. Guarnaccia, C., Scrima, F., \& Civilleri, A (2018). The Role of Occupational Self-Efficacy in Mediating the Effect of Job Insecurity on Work Engagement, Satisfaction and General Health. Curr Psychol, 37, 488-497. https://doi.org/10.1007/s12144016-9525-0

20. Hentrich, S., Zimber, A., Garbade, S. F., Gregersen, S., Nienhaus, A., \& Petermann, F. (2017). Relationships between transformational leadership and health: The mediating role of perceived job demands and occupational self-efficacy. International Journal of Stress Management, 24(1), 34-61.

21. Herman, K.C., Hickmon-Rosa, J. E., \& Reinke, W. M. (2018). Empirically derived profiles of teacher stress, burnout, selfefficacy, and coping and associated student outcomes. J. Posit. Behav. Interv., 20, 90-100.

22. Judge, T. A., \& Bono, J. E. (2001). Relationship of core self-evaluations trait—self-esteem, generalized self-efficacy, locus of control, and emotional stability — with job satisfaction and job performance: A meta-analysis. Journal of Applied Psychology, 86, 80-92.

23. Kelly, K. R., \& Nelson, R. C. (1999). Task-Specific Occupational Self-Efficacy Scale: A predictive validity study. Journal of Career Assessment, 7, 381-392.

24. Kim, L. E., \& Buric', I. (2020). Teacher self-efficacy and burnout: Determining the directions of prediction through an autoregressive cross-lagged panel model. J. Educ. Psychol. 112, 1661-1676. 
25. Kniffin, K. M., Narayanan, J., Anseel, F., Antonakis, J., Ashford, S. P., Bakker, A. B., . . \& Vugt, M. v. (2021). COVID-19 and the workplace: Implications, issues, and insights for future research and action. American Psychologist, 76(1), 63-77. http://dx.doi.org/10.1037/amp0000716

26. Nunes, M. F. O., \& Noronha, A. P. P. (2011). Escala de autoeficácia para atividades ocupacionais: Estudo da estrutura interna e precisão. Avaliação psicológica, 10(1), 25-40.

27. Pepe, S., Farnese, M., Avalone, F., \& Vecchione, M. (2010). Work Self-Efficacy Scale and Search for Work Self-Efficacy Scale: A Validation Study in Spanish and Italian Cultural Contexts.Revista de Psicología del Trabajo y de las Organizaciones, 3, 201- 210

28. Pereira, H., Gonçalves, V. O., \& Assis, R. M. (2021). Burnout, Organizational Self-Efficacy and Self-Esteem among Brazilian Teachers during the COVID-19 Pandemic. Eur. J. Investig. Health Psychol. Educ., 11, $795-803$. https://doi.org/10.3390/ejihpe11030057

29. Runhaar, P., Bednall, T., Sanders, K., \& Yang, H. (2016) Promoting VET teachers' innovative behaviour: exploring the roles of task interdependence, learning goal orientation and occupational self-efficacy. Journal of Vocational Education \& Training, 68:4, 436-452, https://doi.org/10.1080/13636820.2016.1231215

30. Rathi, N., \& Rastogi, R. (2009). Assessing The relationship between emotional intelligence, occupational self-efficacy and organizational commitment. Journal of the Indian Academy of Applied Psychology, 35, 93-102.

31. Rigotti, T., Schyns, B., \& Mohr, G. (2008). A Short Version of the Occupational Self-Efficacy Scale: Structural and Construct Validity Across Five Countries. Journal of Career Assessment, 16(2), 238-255. https://doi.org/10.1177/1069072707305763

32. Salimirad, Fatemeh, \& Srimathi, N. (2016). The Relationship between, Psychological Well-Being and Occupational SelfEfficacy among Teachers in the City of Mysore, India. International Journal of Indian Psychology. 3. https://doi.org/10.25215/0302.037.

33. Schyns, B. (2004). The Influence of Occupational Self-Efficacy on the Relationship of Leadership Behavior and Preparedness for Occupational Change. Journal of Career Development, 30(4), 247-261. https://doi.org/10.1177/089484530403000402

34. Schyns, B., \& von Collani, G. (2002). A new Occupational Self-Efficacy Scale and its relation to personality constructs and organizational variables. European Journal of Work and Organizational Psychology, 11, 219-241.

35. Schyns, B., \& Sczesny, S. (2010). Leadership attributes valence in self-concept and occupational self-efficacy. Career development international, 15 1). 78-92.

36. Shelton, S. H. (1990). Developing the construct of general self-efficacy. Psychological Reports, 66, 987-994.

37. Shoji, K., Cieslak, R., Smoktunowicz, E., Rogala, A., Benight, C.C., \& Luszczynska, A. (2016). Associations between job burnout and self-efficacy: A meta-analysis. Anxiety Stress Coping, 29, 367-386.

38. Slovak, G. (2010). Pre-Service Teacher Self-Efficacy: Theoretical and Research Considerations. The New Educational Review, 2010, 21, 17-30.

39. Speier, C., \& Frese, M. (1997). Generalized self-efficacy as a mediator and moderator between control and complexity at work and personal initiative: A longitudinal field study in East Germany. Human Performance, 10, 171-192.

40. Stajkovic, A. D., \& Luthans, F. (1998). Self-efficacy and work-related performance: A meta-analysis. Psychological Bulletin, $124,240-261$.

41. Schwarzer, R. (1994). Optimistische Kompetenzerwartung: Zur Erfassung einer personellen Bewältigungsressource [Generalized self-efficacy: Assessment of a personal coping resource]. Diagnostica, 40, 105-123.

42. Terry, D., Peck, B., Smith, A., \& Nguyen, H. (2019). Occupational Self-Efficacy and Psychological Capital Amongst Nursing Students: A Cross Sectional Study Understanding the Malleable Attributes for Success. European Journal of Investigation in Health, Psychology and Education, 10(1), 159-172. MDPI AG. https://doi.org/10.3390/ejihpe10010014

43. Thiripurasundari, K., \& Kamini, M. (2016) Impact of emotional intelligence on occupational self-efficacy among women executives: an empirical study in banking industry. Shanlax International Journal of Management, 4(2), 101-110.

44. United Nations Educational, Scientific and Cultural Organization (UNESCO). COVID-19 Educational Disruption and Response; UNESCO: Paris, France, 2020.

\section{Відомості про автора}

Креденцер Оксана Валеріївна, доктор психологічних наук, доцент, провідний науковий співробітник лабораторії організаційної та соціальної психології Інституту психології імені $Г$. С. Костюка НАПН України, Київ, Україна.

Kredentser, Oksana Valeriivna, Dr., Assoc. Prof., leading researcher, Laboratory of organizational and socialpsychology, G.S. Kostiuk Institute of psychology of the NAES of Ukraine, Kyiv, Ukraine.

E-mail:okred278@gmail.com

ORCID ID: https://orcid.org/0000-0003-4119-190X 